\title{
PRIVATISASI RUANG PUBLIK DARI CIVIC CENTRE MENJADI CENTRAL BUSINESS DISTRICT (Belajar dari Kasus Kawasan Simpang Lima Semarang)
}

\author{
Privatization Of Public Space From Civic Centre To Central Business \\ District (A case study of Simpang Lima Area Semarang)
}

\section{Edi Purwanto ${ }^{1}$}

Abstrak : Berdasarkan Rencana Induk Kota Semarang tahun 1975-2005, kawasan Simpang Lima Semarang telah ditetapkan sebagai kawasan Civic Centre yang fokus pengembangannya diarahkan sebagai kawasan pemerintahan dan budaya bagi terciptanya kegiatan yang bersifat publik secara luas bagi masyarakat. Dalam perkembangannya, akibat potensi ekonomi yang sangat besar kawasan tersebut berubah menjadi kawasan Central Business District suatu kawasan dengan ciri-ciri: kegiatan komersial, bangunan berlantai banyak, kepadatan lalu-lintas tinggi, menjamurnya pedagang kaki lima dan berbagai kegiatan lain. Dampak yang muncul adalah privatisasi ruang publik berupa penguasaan kapling/bangunan oleh sekelompok pengusaha perbelanjaan/hotel, pemanfaatan badan jalan untuk parkir kendaraan, serta okupansi jalur pedestrian untuk pedagang kaki lima. Pivatisasi ruag publik telah menghalangi warga kota untuk memanfaatkan ruang publik tersebut dengan leluasa. Permasalahan tersebut layak untuk dikaji sebagai upaya pembelajaran bahwa privatisasi ruang publik akan membawa dampak bagi kehidupan masyarakat secara luas, karena ruang publik memiliki makna penting bagi masyarakat dalam konteks kegunaan, sosial, budaya, sejarah dan politik yang selanjutnya akan memberi makna tertentu bagi ruang tersebut. Kajian ini menggunakan pendekatan deskriptif yaitu berusaha menggambarkan dan menginterpretasi permasalahan privatisasi ruang publik di kawasan Simpang Lima beserta dampak yang ditimbulkannya.

\section{Kata kunci : privatisasi, ruang publik, ruang privat, dampak}

Abstract : Based on The Master Plan of Semarang City from 1975 to 2005, Simpang Lima area has been established as a Civic Centre area which its development is aimed to be a culture area broadly creating public activities for the people. During its development, due to its enormous economic potential, this area has turned into Central Business District area having several characteristics such as commercial activities, multi-storied buildings, heavy traffic, teeming street vendors and others. The impact is privatization of public space in the form of occupying of lots/buildings done by a group of businessmen owning shopping centers/hotels, using of roads for parking lot, and occupancy of pedestrian ways for street vendors. The public place privatization has prevented people to use public space freely. This problem is worthy of study. Public place privatization widely influences people because on the one hand, public place gives important meaning to people in the context of purpose, social, culture, history, and politics; on the other

\footnotetext{
${ }^{1}$ Staff Pengajar Jurusan Arsitektur Fakultas Teknik Universitas Diponegoro

Jl. Prof. Soedharto, SH - Tembalang - Semarang
} 
hand, these people will also give special meaning to this place. This study uses descriptive approach which describes and interprets the problem of public space privatization in Simpang Lima area including its impact.

Keywords: privatization, public space, private area, impact

\section{Pendahuluan}

Krisis perkotaan dapat berupa menurunnya kualitas solidaritas-integrasi sosial dan desain kota. Kerusuhan dan kejahatan massa (mass crime) atau perilaku kolektif yang destruktif (destructive collective action) adalah salah satu bentuk krisis karena lemahnya kualitas kontrol sosial dan rendahnya solidaritas-integrasi sosial. Sedangkan krisis dalam desain kota, dalam UrbanLife Manifesto (1987) dalam Purwanto (2004), berupa : (1) buruknya kondisi kehidupan; (2) hilangnya kontrol warga kota terhadap perkembangan kota; (3) privatisasi yang tinggi sehingga menghilangkan kehidupan publik; (4) fragmentasi sentrifugal; (5) hilangnya makna ruang-ruang kota; (6) ketidakadilan; (7) profesionalisme yang tidak berakar pada kehidupan dan kebutuhan kota.

Privatisasi ruang pulbik yang terjadi di kota-kota besar di Indonesia kerapkali menimbulkan permasalahan sosial yang sangat kompleks. Meskipun privatisasi ruang publik berbasis pada faktor ekonomi, namun permasalahan yang ditimbulkannya lebih banyak berdimensi sosial seperti misalnya konflik pemanfaatan ruang. Pengertian sederhana dari Ruang publik atau yang sering dikenal dengan public space, merupakan sebuah tempat yang dapat digunakan oleh masyarakat luas dalam rangka memenuhi kebutuhannya. Ruang publik atau ruang terbuka yang dapat diakses oleh masyarakat tanpa mengeluarkan biaya (Radjawali, 2004).

Berbicara mengenai kepemilikan ruang publik, sebagian para ahli beranggapan bahwa ruang publik seharusnya dikuasai oleh pemerintah. Hal itu bertujuan untuk menghindari penyalahgunaan fungsi oleh pihak swasta yang cenderung digunakan sebagai ruang komersial sehingga ruang publik tersebut dapat memberikan pelayanan yang optimal kepada masyarakat tanpa harus mengeluarkan biaya. Permasalahan klasik yang terjadi selama ini adalah lemahnya "law enforcement", beberapa ruang publik berubah fungsi menjadi ruang privat dengan dalih perkembangan kota. Rencana Tata Ruang Wilayah (RTRW) kota yang telah disusun dengan biaya mahal pada akhirnya menjadi arsip yang disimpan dalam lemari karena tidak mampu menjadi instrumen penataan kota meskipun di dalamnya telah diatur substansi perencanaan dan perancangan kota yang sudah cukup baik dan memenuhi azas kebutuhan masyarakat (Purwanto, 2010).

Privatisasi ruang publik di kawasan Simpang Lima Semarang pada dasarnya telah terjadi sejak awal tahun 1980-an, ketika kawasan ini mulai berkembang menjadi pusat kegiatan ekonomi kota yaitu ketika dibangunnya pusat perbelanjaan di sisi Timur lapangan Pancasila kemudian diikuti dengan pembangunan perbelanjaan lain di sisi Barat lapangan Pancasila (diantaranya terdapat pusat hiburan EP plaza) dan akhirnya berturut-turut dibongkarnya gedung pertemuan Wisma Pancasila menjadi Plaza Simpang Lima serta dibongkarnya Gedung Olah Raga (GOR) menjadi hotel dan mal Citraland. Pembongkaran bangunan-bangunan lama yang notabene adalah bangunan publik milik pemerintah kota/propinsi menjadi indikasi bahwa telah terjadi privatisasi karena pada awalnya masyarakat dapat menikmati kegiatan-kegiatan publik dalam bangunanbangunan tersebut, namun kemudian menjadi tempat privat seperti mal misalnya. Meskipun mal merupakan bangunan publik namun kepemilikan/penguasaannya adalah privat sehingga mempunyai perbedaan perlakukan dalam pemanfaatannya. Dampak berkembangnya kawasan ini menjadi pusat kegiatan ekonomi adalah munculnya kegiatan-kegiatan ekonomi informal yang lain seperti PKL dan parkir resmi dan parkir liar yang mengokupansi jalur pedestrian atau badan jalan 
yang notabene adalah ruang publik. Selain itu pemasangan baliho atau papan reklame juga dituduh menjadi penyebab privatisasi ruang publik ketika masyarakat mendapatkan hal tentang visual kota yang indah namun justru mendapatkan visual kota yang semramut.

Pada awalnya, permasalahan yang terjadi di kawasan Simpang Lima belum pernah didefinisikan privatisasi ruang publik, melainkan fungsi privat makin menggerogoti ruang publik. Ruang kota seperti kawasan Simpang Lima seharusnya adalah ruang yang terbuka lebar-lebar dan gratis bagi warga kota. Privatisasi ruang publik ${ }^{2}$ yang terjadi di kawasan ini adalah akibat tidak konsistensinya pihak penentu kebijakan dalam menerapkan Rencana Kota, dan celakanya penguasaan privat atas ruang publik itu didukung oleh penentu kebijakan. Dengan begitu itu, lantas apa gunanya ada Rencana Induk Kota kalau dalam pengejawantahannya banyak terjadi apa yang disebutkan Marion Shoard sebagai corruption in the process of planning and implementation? ${ }^{3}$

Tulisan ini merupakan kajian dari permasalahan ruang kota yang berakar dari privatisasi ruang publik, kemudian dibahas dengan tujuan agar menjadi pembelajaran kita semua bahwa terjadinya privatisasi ruang publik yang berbasis pada aspek ekonomi akan berdampak pada aspek fisik, sosial, politik dan budaya masyarakat.

\section{Metode Kajian}

Kajian ini menggunakan pendekatan penelitian deskriptif, yaitu suatu bentuk penelitian yang ditujukan untuk mendeskripsikan fenomena-fenomena yang ada, baik fenomena alamiah maupun fenomena buatan manusia. Fenomena itu bisa berupa bentuk, aktivitas, karakteristik, perubahan, hubungan, kesamaan, dan perbedaan antara fenomena yang satu dengan fenomena lainnya (Sukmadinata, 2006). Penelitian deskriptif merupakan penelitian yang berusaha mendeskripsikan dan menginterpretasikan sesuatu, misalnya kondisi atau hubungan yang ada, pendapat yang berkembang, proses yang sedang berlangsung, akibat atau efek yang terjadi, atau tentang kecenderungan yang tengah berlangsung.

Furchan (2004) menjelaskan bahwa penelitian deskriptif adalah penelitian yang dirancang untuk memperoleh informasi tentang status suatu gejala saat penelitian dilakukan. Lebih lanjut dijelaskan, dalam penelitian deskriptif tidak ada perlakuan yang diberikan atau dikendalikan serta tidak ada uji hipotesis sebagaimana yang terdapat pada penelitian eksperiman.

\section{Privatisasi Ruang Publik Dalam Ruang Kota: Kajian Teori}

Ruang kota bukanlah rongga tiga dimensi geometri yang dapat diterjemahkan begitu saja dalam bentuk peta-peta. Dinamika kota harus dilihat melalui apa yang disebut Lefebvre (1991) sebagai ruang sosial, yaitu ruang sebagai produk sosial dengan berbagai macam aktifitas orang di dalamnya. Berdasarkan penjelasan Lefebvre, dikatakan bahwa ruang kota adalah ruang publik apabila ruang kota tersebut memproduksi ruang sosial ketika orang-orang beraktifitas didalamnya.

Menurut Purwanto (2008), beberapa aspek-aspek yang harus dipahami untuk dapat menjelaskan ruang publik. Pertama, ruang publik adalah sebagai wahana interaksi antar komunitas untuk berbagai tujuan, baik individu maupun kelompok. Dalam hal ini ruang publik merupakan bagian dari sistem sosial masyarakat yang keberadaannya tidak dapat dilepaskan dari dinamika sosial. Disamping itu, ruang publik juga berfungsi memberikan nilai tambah bagi

2 Menurut Kamus Kata-Kata Serapan Asing dalam Bahasa Indonesia karangan JS Badudu, 2003; Privatisasi diartikan sebagai proses perbuatan milik perseorangan dari yang tadinya milik negara, disebut juga proses swastanisasi. Privatisasi ruang publik diartikan sebagai upaya perubahan kepemilikan ruang dari yang tadinya milik umum (publik) menjadi milik pribadi (privat).

${ }^{3}$ Dalam http://www.kompas.com/kompas-cetak/0110/24/metro/kemb18.htm 
lingkungan, misalnya segi estetika kota, pengendalian pencemaran udara, pengendalian iklim mikro, serta memberikan "image" dari suatu kota. Kedua adalah aspek aksesibel tanpa terkecuali (accessible for all) dimaksudkan bahwa ruang publik seyogyanya dapat dimanfaatkan oleh seluruh warga kota yang membutuhkan. Ketiga adalah universalitas dimaksudkan bahwa penyediaan ruang publik seyogyanya dapat mempertimbangkan berbagai kelas dan status kebutuhan masyarakat yang mencerminkan pemenuhan kebutuhan seluruh lapisan masyarakat baik kelas atas sampai bawah, dari yang normal sampai difabel, dari anak-anak sampai dewasa dan pria atau wanita. Lebih jauh, ruang publik merupakan sarana kekuatan relasi sosial masyarakat yang karakternya dapat dilihat seperti mengizinkan berbagai kumpulan/grup penduduk berada di dalamnya, serta menghargai kelas-kelas masyarakat, perbedaan etnis, jender, dan perbedaan umur. Walaupun secara umum, ruang ini bisa diakses semua manusia, namun harus tetap mengikuti norma untuk tidak merugikan kepentingan umum di dalamnya. Keempat, ruang publik disebut bermakna bila ada kepublikan atau publicness. Kalau tidak ada publicness, maka tidak akan ada yang memanfaatkan ruang publik. Kepublikan itu mensyaratkan adanya tingkat kolektivitas tertentu. Di dalam ruang publik berbicara tentang sosial intercourse atau pergaulan sosial antar manusia dalam sistem produksi.

Menurut Krier (1979), ruang kota adalah ruang-ruang geometris yang dibatasi oleh elevasi-elevasi : sebuah ruang luar yang terbuka, bebas halangan sehingga memungkinkan pengaliran segala macam pergerakan dan bersifat publik. Ruang ini pada dasarnya terdiri dari dua macam bentuk yaitu jalan (street) dan lapangan (square). Square merupakan ruang terbuka yang bersifat statis seperti alun-alun, lapangan bermain, dan taman kota yang biasanya bersifat memusat dan berorientasi ke dalam. Street merupakan ruang terbuka kota yang bersifat dinamis seperti jalan raya, jalur pejalan kaki, dan jalur setapak yang biasanya bersifat linier dan berorientasi kedua ujungnya. Ruang terbuka publik (public open space) di perkotaan dapat dipahami sebagai bagian dari ruang kota (urban space) yang dimanfaatkan oleh warga kota secara tidak terkecuali untuk menyalurkan hasrat dasarnya sebagai mahluk sosial yang membutuhkan wadah untuk berinteraksi dan berkomunikasi.

Menurut Huat (1992), public space (ruang publik) berdasarkan lokasinya dibagi menjadi dua, yakni out door public space dan indoor public space. Outdoor public space menjelaskan public space yang berada di luar bangunan misalnya : plasa, lapangan, jalan, jalur pedestrian, taman terbuka, sedangkan indoor public space untuk menjelaskan public space yang berada di dalam bangunan misalnya pusat-pusat perbelanjaan (mal), gedung pertemuan.

Ruang terbuka kota yang bersifat publik adalah ruang kota yang mengakomodasi kegiatan masyarakat umum. Rancangan ruang semacam ini harus mempertahankan beberapa faktor pencapaian yang berdasar pada kegiatan yaitu (Whyte, 1980) :

1. Faktor Fisik, yaitu keterkaitan antara kawasan yang dihubungkan dengan sirkulasi;

2. Faktor visual, yaitu pengembangan kemudahan orang mendapatkan gambaran visual;

3. Faktor simbolis, yaitu kawasan yang mampu mengembangkan nilai-nilai sejarah dan budaya.

Menurut Carr (1992), ruang terbuka publik merupakan tempat yang memiliki fungsi sebagai ruang kegiatan menetap dan rutin yang menyediakan sarana dan prasarana yang dapat menunjang kegiatan komunikasi, bermain dan bersantai. Prasarana ini merupakan kebutuhan yang sangat diperlukan di ruang terbuka untuk dapat membantu manusia dalam mendapatkan kepuasan, perlindungan, dan kehidupan sosial yang tertata dengan baik. Ruang publik bagi pengguna seharusnya memiliki 3 nilai, yaitu :

1. Reponsif (responsive); ruang publik harus didesain dan diatur untuk melayani kebutuhan pengguna. Kebutuhan masyarakat yang utama adalah mencari kepuasan di ruang publik yang berkaitan dengan kenyamanan, relaksasi, kegiatan-kegiatan aktif/pasif. Ruang publik juga dapat diatur secara fisik dan rohani yang bermanfaat bagi keseimbangan hidup masyarakat.

2. Demokratis (democratic); ruang publik melindungi hak-hak kelompok pengguna juga dapat menerima semua kelompok dan menyediakan kebebasan terhadap aksi dan juga terhadap tuntutan serta kepemilikan. Dalam ruang publik masyarakat dapat belajar hidup bersamasama. 
3. Penuh Makna (Meaningful); ruang publik memberikan orang-orang untuk membuat hubungan yang kuat antara tempat (place), kehidupan perorangan, dan kelompok yang lebih besar dan berusaha untuk menghubungkan fisik dengan konteks sosial dan budaya. Ruang terbuka yang dihubungkan dengan kesejarahan atau tumpang tindih dengan memori individu/kelompok serta pengalaman-pengalaman membuat suatu menjadi berharga bagi suatu masyarakat tertentu.

Ruang terbuka publik mempunyai hubungan yang erat dengan masyarakat kota. Ruang kota ini mudah dijangkau oleh umum, baik secara visual maupun secara fisik. Penilaian aspek visual suatu kawasan terhadap bentuk kota merupakan hasil interaksi antara masyarakat dengan lingkungan kota, yaitu persepsi manusia mengenai karakter ruang yang berkaitan dengan aspek alami (natura) dan budaya (cultura). Persepsi tersebut timbul akibat adanya interaksi antara pengamat dengan obyek amatan yang dipengaruhi oleh jarak amatan dalam ruang (Garnham, 1985).

Ruang publik di pusat kota merupakan kawasan yang sangat menonjol dalam pertumbuhannya, hal ini didorong oleh berbagai macam aktifitas diantaranya : perdagangan, hiburan/rekreasi, budaya dan pemerintahan. Oleh karena itu ruang publik di kawasan pusat kota memiliki makna penting bagi masyarakat dalam konteks kegunaan, budaya, sejarah dan politik yang selanjutnya akan memberi makna tertentu bagi ruang tersebut (Beisi, 1997).

Zahnd (1999) mengatakan bahwa pengertian public space dan open space secara umum tidak selalu dipahami berdasarkan pandangan yang sama apabila open space dilihat menjadi sesuatu pengertian yang subjektif. Oleh karena itu open space harus dilihat dan dipahami secara objektif dengan memperhatikan tiga prinsip berikut : (1) open space adalah ruang terbuka yang lebih berarti daripada sesuatu yang kosong saja; (2) open space dibentuk secara organis atau teknis oleh benda-benda yang membatasinya; (3) open space dapat dibagi empat aspek yang fungsional, yaitu (a) public space : fokus kota, (b) semi public space : fokus kota, (c) semi private space : fokus rumah/bangunan, (d) private space : fokus rumah/bangunan

Senada dengan Zahnd, Siswanto (dalam Budihardjo, 1997) mengatakan bahwa dalam menjelaskan perkara lingkungan manusia di kota menekankan perlunya memahami konsep privat sebagai konsep dua sisi yang berlawanan terhadap konsep publik. Selanjutnya konsep publik diartikan sebagai keleluasaan manusia dalam ruang untuk berinteraksi sosial dan komunikasi. Dikotomi ini kemudian direntangkan dalam enam kategori ruang dalam berbagai skala :

1.Ruang privat perseorangan seperti kamar tidur

2.Ruang privat keluarga/kelompok kecil

3. Ruang privat kelompok besar

4. Ruang semi-publik (kantor, balaikota, pelabuhan udara dan sebagainya)

5.Ruang publik kelompok besar (stadion, taman rekreasi, pertokoan/mal)

6. Ruang publik kota (lapangan, plasa, jalan, sungai)

Ruang publik merupakan ruang untuk mempromosikan sekaligus menghargai hak untuk berbeda. Ekspresi perbedaan, spontanitas, dan kreativitas adalah bagian dari kehidupan seharihari pada ruang publik. Ruang publik harus bebas biaya, bebas dari rasa takut, terbuka untuk berbagai kalangan termasuk orang miskin, dan bebas dari hambatan fisik. Jalan, taman, dan lapangan terbuka adalah ruang publik yang membuat kita kontak dan hidup bersama perbedaan. Kebebasan individu dan kelompok diakui asalkan tidak mengganggu yang lain. Akan tetapi, ini pun mendapat tantangan semenjak privatisasi ruang publik. Bukan hanya ruang publik yang diubah menjadi komersial, melainkan juga penciptaan ruang publik oleh sektor privat. Di sisi lain, banyak ruang publik yang sengaja diciptakan pemerintah, atau ruang publik formal, kalah populer dibanding dengan yang diciptakan sektor privat. $^{4}$

\footnotetext{
${ }^{4}$ Dijelaskan oleh Yudi Dzulfadli Baihaqi dalam http://www.pikiran-rakyat.com/cetak/0303/06/0804.htm
} 


\section{Gambaran Umum Kawasan Simpang Lima Semarang}

Kawasan Simpang Lima berkembang awal tahun 1990-an sebagai kawasan CBD setelah sebelumnya di arahkan sebagai kawasan Civic Centre. Fenomena perubahan yang terjadi di kawasan ini merupakan gejala alamiah yang juga terjadi di kota-kota besar lainnya di Indonesia. Kekuatan ekonomi merupakan faktor pendorong utama yang menyebabkan perubahan. Inti fisik kawasan Simpang Lima adalah lapangan Pancasila yang dikelilingi oleh beberapa bangunan yang membentuk enclosure. Bangunan-bangunan yang membentuk enclosure tersebut mempunyai fungsi yang beragam : perdagangan, jasa, sosial (masjid dan sekolah) dan perkantoran. Masih terdapat bangunan dengan fungsi sosial memberikan gambaran masih terdapat jejak fisik kawasan tersebut awalnya dikembangkan bukan sebagai kawasan perdagangan. Kawasan Simpang Lima merupakan pertemuan lima ruas jalan utama, yaitu jalan Pandanaran, jalan Gadjahmada, jalan KH.Ahmad Dahlan, jalan Ahmad Yani dan jalan Pahlawan. Kelima ruas jalan tersebut dipertemukan oleh jalan satu arah yang mengelilingi lapangan Pancasila.

Dampak perkembangan kawasan Simpang Lima yang sangat pesat mengakibatkan pula perkembangan pada sektor-sektor lain, misalnya jumlah pedagang kaki lima yang semakin banyak, kepadatan lalu-lintas kendaraan bermotor, meningkatnya jumlah media ruang luar berupa billboard, spanduk. Meskipun kawasan Simpang Lima masih menjadi tujuan utama masyarakat yang memanfaatkannya, namun implikasi dari dampak perkembangan tersebut adalah menurunnya kualitas ruang kota terutama keberadaan ruang publik yang nyaman dan aman yang selama ini menjadi harapan masyarakat.

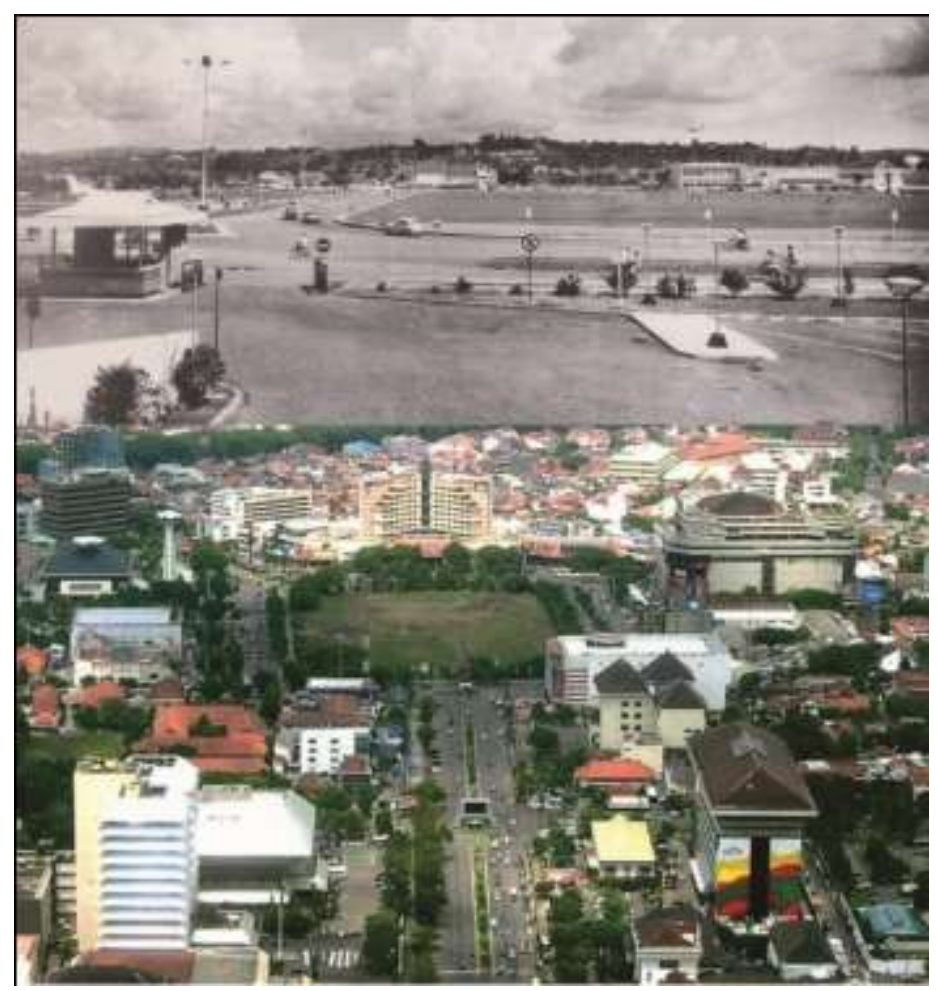

Sumber: dokumentasi penulis

\section{Gambar 1. Kondisi Kawasan Simpang Lima tahun 1970-an (atas) dan Foto Udara Kawasan Simpang Lima} kondisi sekarang (bawah) 


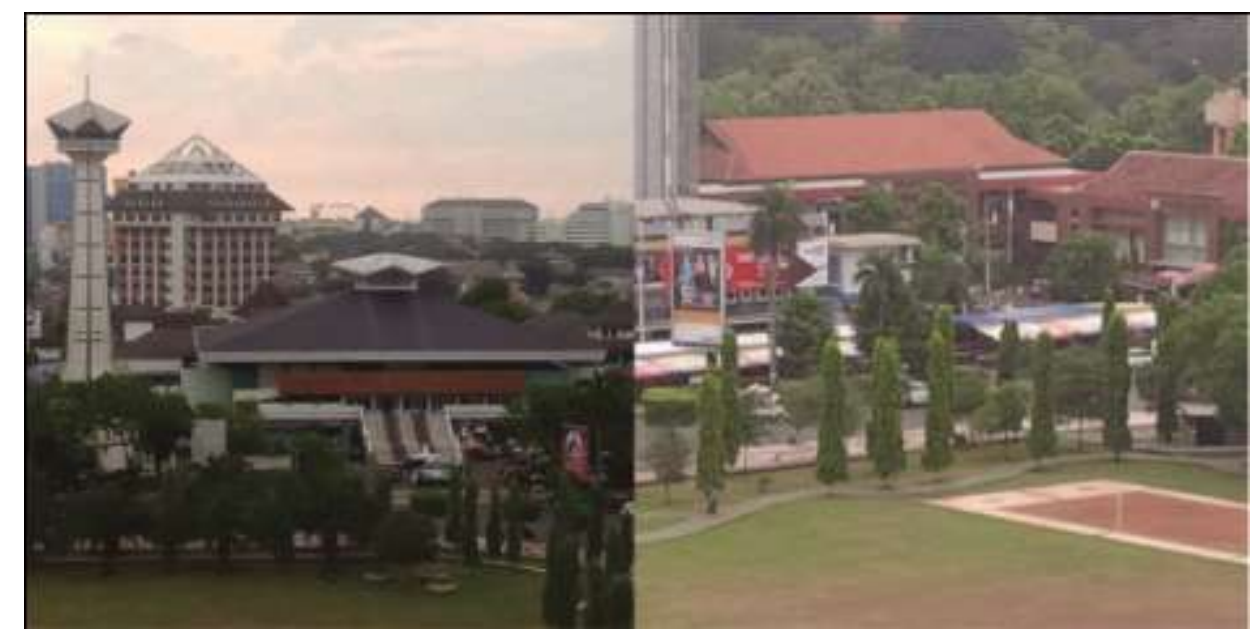

Sumber: dokumentasi penulis

\section{Gambar 2. Masjid Baiturrahman (kiri) dan STM Pembangunan (kanan) merupakan dua bangunan yang tersisa sesuai dengan fungsi kawasan Simpang Lima sebagai pusat pemerintahan, pendidikan, dan kebudayaan sesuai RIK tahun 1975}

\section{Privatisasi Ruang Publik Di Kawasan Simpang Lima Dari Masa Ke Masa}

Keinginan untuk menciptakan sebuah ruang publik yang memenuhi berbagai aspek ternyata bukan perkara yang mudah. Meski di awal perkembangannya kawasan Simpang Lima Semarang dirancang sebagai ruang kota yang mengedepankan ruang publik atau ruang terbuka sebagai elemen utamanya, namun saat ini pemanfaatannya jauh dari yang dirancang. Kawasan Simpang Lima pada tahun 1970 - 1980 an, ketika itu masyarakat masih dapat menikmati fasilitas ruang publik dengan baik. Tidak hanya ruang publik berupa lapangan terbuka (outdoor), namun juga ruang publik tertutup (indoor) seperti Gedung Olah Raga (GOR), Wisma Pancasila yang seringkali digunakan oleh masyarakat untuk kegiatan sosial, seni dan budaya. Dua bangunan fasilitas sosial tersebut sekarang sudah berganti menjadi pusat perbelanjaan dan hotel yang sangat megah. Pada kondisi sekarang, ruang publik di kawasan Simpang Lima semakin jauh dari gambaran sebagai tempat berinteraksi yang nyaman, memadai dan aman. Kalau tidak kotor dan semrawut oleh aktifitas pedagang kaki-lima dan parkir on-street, ruang publik tersebut rawan terhadap tindak kriminal, bahkan ada pula yang sulit diakses publik secara bebas akibat munculnya berbagai macam bangunan jasa dan komersial yang lebih "selektif" terhadap masyarakat yang memanfaatkannya. Kecenderungan pasar bebas dengan privatisasi mengubah ruang publik menjadi ruang-ruang privat.

Gangguan, pembatasan maupun larangan untuk meng-akses ruang publik oleh masyarakat di kawasan ini sudah mengarah kepada upaya privatisasi baik secara formal maupun nonformal. Masyarakat berharap bahwa ruang publik di kawasan ini sebaiknya dapat mempertimbangkan berbagai kelas dan status kebutuhan masyarakat yang mencerminkan pemenuhan kebutuhan seluruh lapisan masyarakat baik kelas atas sampai bawah, dari yang normal sampai difabel, dari anak-anak sampai dewasa dan pria atau wanita. Walaupun secara umum, ruang ini bisa diakses semua lapisan masyarakat, namun harus tetap mengikuti norma untuk tidak merugikan kepentingan umum di dalamnya.

\section{GOR \& Wisma Pancasila menjadi Pusat Perbelanjaan}

Bagi warga kota Semarang tentu masih ingat ketika tahun 1975 di kawasan Simpang Lima dibangun Gedung Olah Raga (GOR) yang cukup megah yang konon dapat bertahan kekuatan 
fisiknya sampai 100 tahun. Keberadaan GOR bagi warga kota dirasakan sangat mendukung kegiatan warga yang bersifat publik, tidak hanya kegiatan olah raga saja namun juga kegiatan sosial budaya lainnya seperti pentas seni, pameran, festival dan sebagainya. Demikian pula Wisma Pancasila yang berfungsi pula sebagai tempat untuk kegiatan masyarakat yang bersifat publik seperti pameran, diskusi, seminar, sarasehan dan sebagainya. Sifat publik yang dimunculkan oleh kedua bangunan tersebut memberikan kontribusi terhadap kehidupan kawasan Simpang Lima secara umum. Akibat tekanan ekonomi yang cukup kuat akhirnya kedua bangunan tersebut dirobohkan menjadi bangunan perbelajaan (mal) dan hotel yang cukup megah. Bagi warga kota Semarang tentulah kedua bangunan tersebut pada umumnya menyandang nilai "ingatan kolektif" atau "collective memory" (Rossi, 1982). Ingatan kolektif bukanlah sekedar kenangan atau pengalaman yang berkesan dari orang banyak terhadap suatu bangunan, melainkan lebih ke arah terbangunnya ikatan emosional dan spiritual dari orang banyak terhadap bangunan dalam konteks ruang kota.

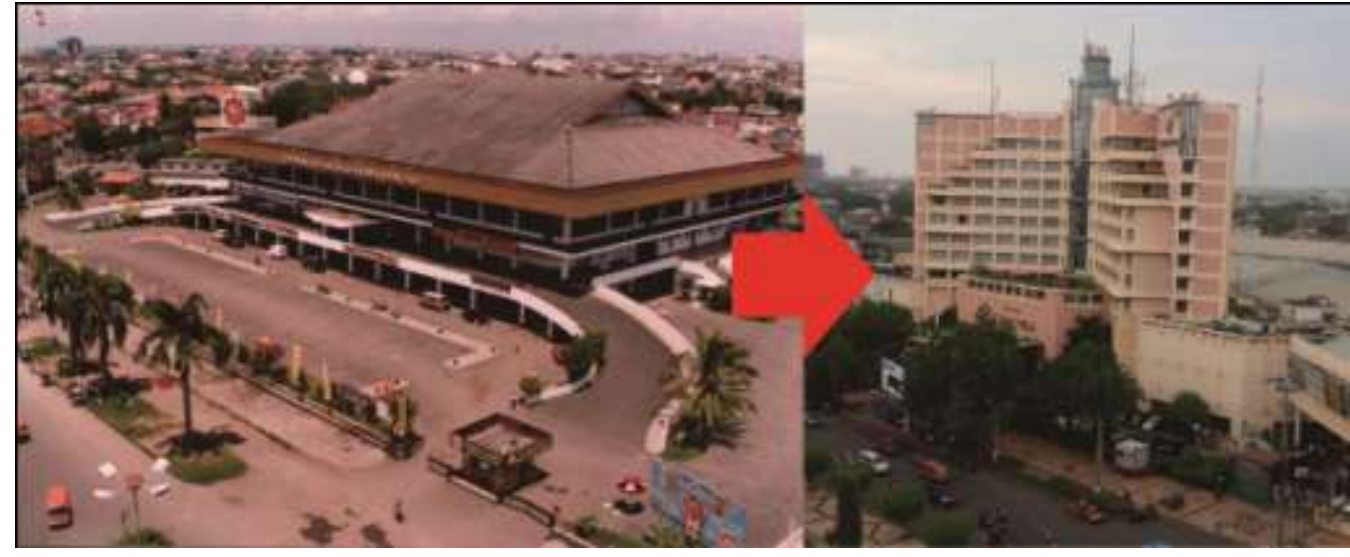

Sumber: dokumentasi penulis dan survey lapangan, 2014

\section{Gambar 3. Kondisi GOR tahun 1979 (kiri) menjadi Pusat Perdagangan (Mal dan hotel Citraland) sekarang (kanan)}

Perubahan kedua bangunan tersebut diatas menjadi bangunan perbelanjaan dan hotel pada akhirnya juga merubah fungsi dari publik menjadi "privat". Meskipun Siswanto (dalam Budihardjo, 1997) mengatakan bahwa stadion, gedung pertemuan dan pertokoan/mal merupakan ruang publik kelompok besar, namun ada perbedaan sifat kepublikan maupun keprivatannya. GOR dan Wisma Pancasila lebih cenderung sebagai ruang publik (indoor) karena sifat kegiatannya yang lebih banyak untuk kegiatan sosial dan budaya dimana akses warga untuk dapat memanfaatkannya jauh lebih plural. Sedangkan pusat perbelanjaan/mal meskipun digunakan untuk publik namun masih ada "seleksi" terhadap warga yang memanfaatkannya. Seperti mal-mal yang ada, sebenarnya milik pribadi yang dibuka sebagai ruang publik. Konsep kepublikan semacam itu sangat semu, karena kita tidak bisa berbuat apa-apa kecuali sebagai konsumen yang berbelanja, cenderung hanya dapat dinikmati oleh kelompok masyarakat menengah ke atas dibandingkan dengan kelompok menengah bawah. Mal menjadi pulau terasing di mana orang dapat hidup egois tanpa merasa bersalah. Mal adalah ruang publik yang introvert, yang membalikkan diri, memberikan punggungnya terhadap ruang 'publik' lain, yaitu lapangan parkir yang mengelilinginya. ${ }^{5}$ Disinilah pada akhirnya proses privatisasi ruang publik telah terjadi. Kawasan yang pada awalnya diharapkan menjadi kawasan publik berubah menjadi "kontainer"

\begin{tabular}{cccc}
\hline 5 & Menurut Marco Kusumawijaya dalam http://www.dbp.kerjabudaya.org/program/p- \\
$\underline{2000 / d b p}$ & 18052000 ruang publik.htm
\end{tabular}


atau kawasan yang bangunan-bangunannya menampung berbagai benda sekaligus melindungi isinya dari luar. Gejala ini muncul sebagai kapitalisme lanjut masyarakat konsumtif dimana pengembangan kawasan yang berbasis ekonomi belum lengkap bila tidak menyertakan mal sebagai ikonnya.

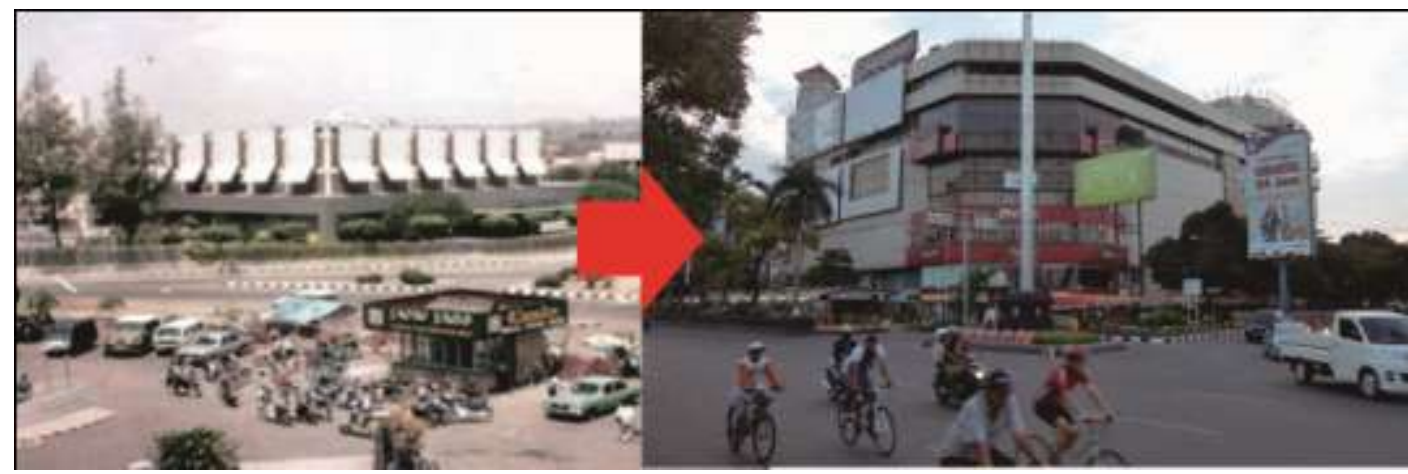

Sumber: dokumentasi penulis dan survey lapangan, 2014

Gambar 4. Wisma Pancasila tahun 1981 (kiri) sekarang menjadi Pusat Perbelanjaan (Matahari Department Store) dan hotel Horison (kanan)

\section{Jalur Pedestrian menjadi Tempat Berdagang Sektor Informal}

Sering dijumpai dalam ruang terbuka publik, dipergunakan oleh pedagang informal. Timbulnya kegiatan tersebut disebabkan oleh inetraksi dengan masyarakat pengguna ruang publik dalam bentuk prinsip demand dan supply. Dalam hal ini terkandung makna terjadinya penggunaan formal space untuk aktifitas informal sector. Menurut Laguerre (1994), sektor informal merupakan hidden space atau sisi belakang layar kota sebagai sebuah etos informal yang tak terucap dengan alam yang sangat sensitif, un-etis dan illegal.

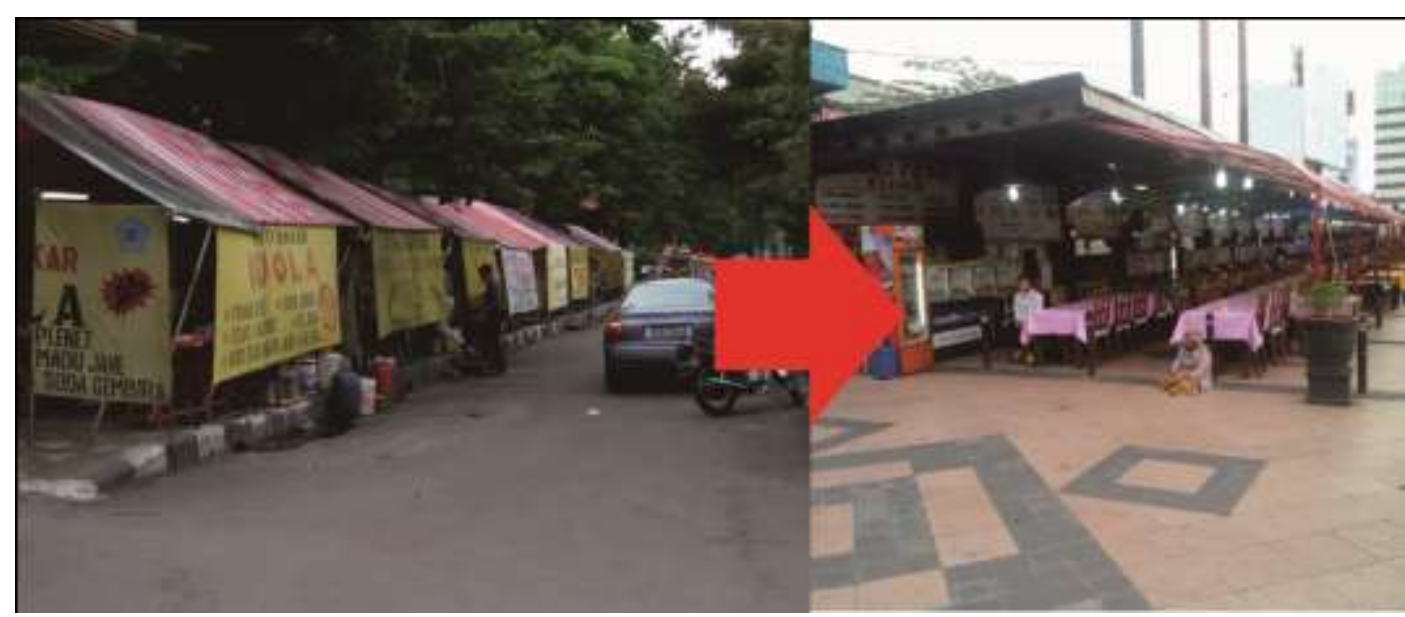

Sumber: dokumentasi penulis dan survey lapangan, 2014

Gambar 5 : PKL di sisi Timur Lapangan Pancasila di atas jalur pedestrian sebelum ada penataan (kiri), setelah ditata jalur lambat menjadi satu nampak lebih asri namun tempat dasaran PKL makin luas dan mempersempit jalur pejalan kaki 
Dalam kenyataannya, keberadaan para pedagang informal di ruang publik di kawasan Simpang Lima jarang direncanakan secara terintegrasi dalam perancangan kota, sehingga mereka muncul secara spontan di ruang publik (di jalur pedestrian, badan jalan) dan baru dilakukan "pengaturan" bila pengguna ruang publik merasa "terganggu" atau untuk kepentingan lainnya. Permasalahan tersebut diatas memunculkan paradoks, disatu sisi pedagang informal sangat dibutuhkan kehadirannya sebagai bagian kehidupan ruang kota, namun disisi lain menjadi permasalahan apabila aktifitasnya menempati tempat/ruang publik yang seharusnya menjadi "hak" warga untuk memanfaatkannya. Disinilah pada akhirnya proses privatisasi ruang publik telah terjadi. Meskipun proses privatisasinya lebih cenderung terjadi secara informal (kegiatannya juga bersifat informal), namun tidak sesuai dengan prinsip-prinsip ruang publik yang dikatan oleh Carr (1992) bahwa ruang publik harus memiliki nilai demokratis (democratic); ruang publik melindungi hak-hak kelompok pengguna juga dapat menerima semua kelompok dan menyediakan kebebasan terhadap aksi dan juga terhadap tuntutan serta kepemilikan. Dalam ruang publik masyarakat dapat belajar hidup bersama-sama.

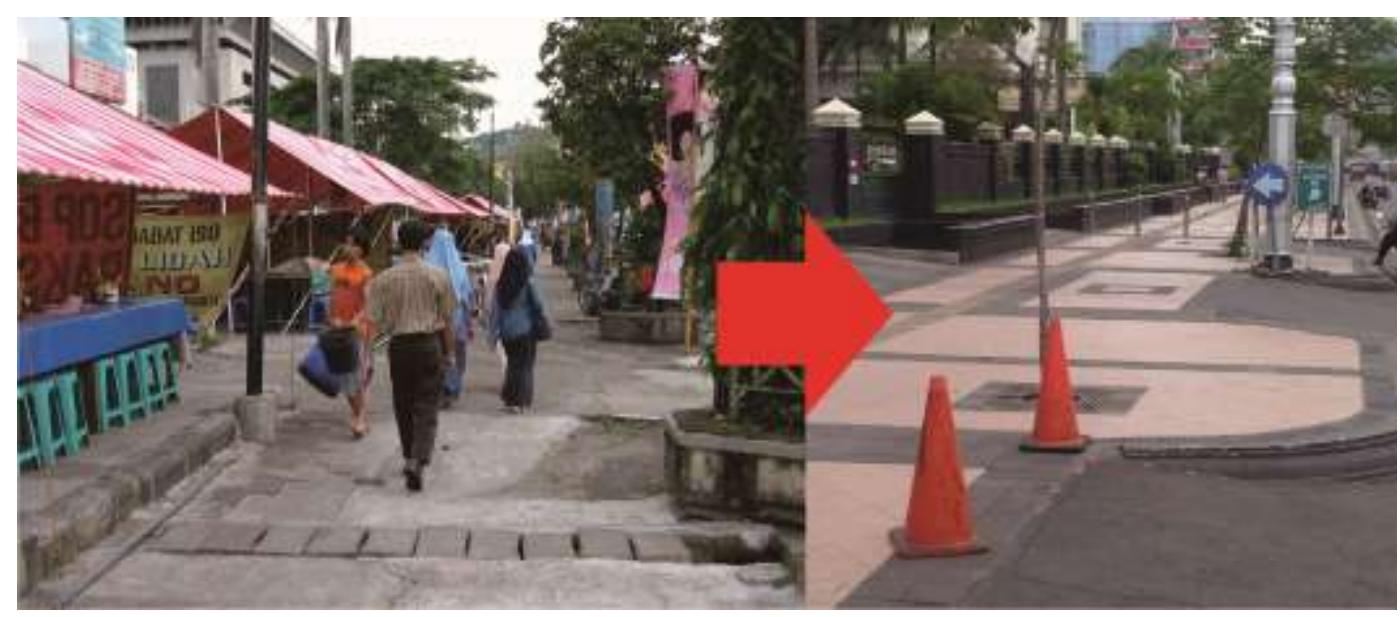

Sumber: dokumentasi penulis dan survey lapangan, 2014

Gambar 6. PKL di atas jalur pejalan kaki di sisi Timur jalan Pahlawan sebelum direlokasi (kiri), setelah ditata lingkungannya PKL diminta berpindah tempat dan sekarang dikembalikan fungsinya sebagai jalur pejalan kaki (kanan) - ini adalah salah satu wujud kepedulian pemerintah kota kepada masyarakatnya.

\section{Kesemrawutan Transportasi dan Parkir On-Street}

Fenomena pertumbuhan kawasan yang diakibatkan oleh kegiatan ekonomi seperti di kawasan Simpang Lima yang lebih berorientasi pada pengunjung yang menggunakan kendaraan bermotor mengakibatkan pengunjung yang berjalan kaki memerlukan perjuangan yang khusus untuk dapat memanfaatkannya, belum lagi kalau hal ini dikaitkan dengan kelompok masyarakat yang kurang beruntung karena keterbatasan fisik (difabel).

Kawasan Simpang Lima terutama pada hari libur mendapatkan tekanan bangkitan lalulintas yang sangat luar biasa mengakibatkan kemacetan dan sangat tidak nyaman untuk bertransportasi. Banyak warga masyarakat yang ingin ke lapangan Pancasila harus berjuang dengan keras untuk dapat menyeberang jalan. Keadaan tersebut diperparah dengan sempitnya penyediaan lahan parkir, banyak kendaraan bermotor yang diparkir di sembarang tempat, merampas badan jalan bahkan jalur pedestrian. Parkir kendaraan di badan jalan (on-street) selain bersifat legal karena dikelola oleh pusat perbelanjaan juga bersifat illegal.

Penguasaan lahan-lahan parkir oleh pihak-pihak legal maupun illegal merupakan proses privatisasi ruang publik, karena badan-badan jalan, jalur pedestrian yang seharusnya digunakan 
oleh publik "dikuasai" dan "dimiliki” oleh pihak-pihak legal dan illegal tersebut. Ruang publik sebagai tempat berjalan-jalan menikmati suasana telah diprivatkan, dan menjadi lahan komersial demi keuntunyan pribadi. Dengan demikian, beberapa fenomena seperti penguasaan pemanfaatan badan jalan dan jalur pedestrian untuk on-site parking, telah menghalangi warga kota untuk memanfaatkan ruang publik tersebut.

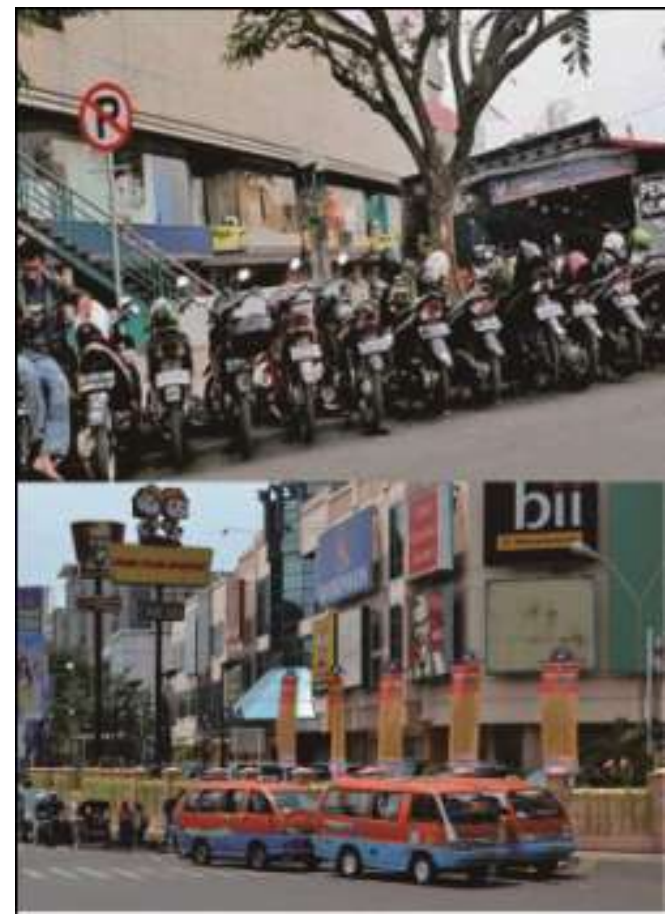

Sumber: survey lapangan, 2014

\section{Gambar 7 : Parkir on-street kendaraan roda 2 di dekat larangan parkir (atas) dan sejumlah angkutan kota berhenti menunggu penumpang di dekat larangan berhenti (bawah)}

Hal tersebut tentunya tidak sesuai dengan prinsip bahwa ruang terbuka kota yang bersifat publik adalah ruang kota yang mengakomodasi kegiatan masyarakat umum. Rancangan ruang semacam ini harus mempertahankan beberapa faktor pencapaian dan sirkulasi yang berdasar pada kegiatan yaitu keterkaitan antara kawasan yang dihubungkan dengan sirkulasi dan transportasi (Whyte, 1980).

\section{Media Ruang Luar}

Kehadiran media ruang luar (outdoor signs) di kawasan Simpang lima tampaknya cenderung lebih memanfaatkan potensi ekonomi kawasan daripada memandang sebagai elemen urban design yang harus memperhatikan keberadaan properti fisik dan nilai-nilai estetika di kawasan tersebut.

Media ruang luar yang ada di kawasan ruang publik Simpang Lima digolongkan menjadi empat jenis, yaitu (Riyadi, 2002):

a. Mal Identity, merupakan identitas mal yang terletak di fasade bangunan mal supaya mudah dikenali;

b. $\quad$ Traffic Sign, berupa papan petunjuk arah jalan dan rambu lalu-lintas;

c. Commercial Identity, berupa billboard, baliho, cover banner yang sangat mendominasi kawasan ini dengan bentuk dan skala yang sangat besar; 
d. Information Sign, berupa papan informasi dan spanduk.

Keberadaan media luar luar di kawasan Simpang Lima terutama yang berbentuk commercial identity sangat mengganggu kualitas visual ruang publik karena bentuk, ukuran dan estetika yang tidak diperhatikan. Masing-masing perusahaan advertensi berlomba-lomba untuk menampilkan media iklan agar berbeda antara satu dengan yang lainnya baik dari segi bentuk maupun ukuran yang cenderung sangat besar dan tidak manusiawi.

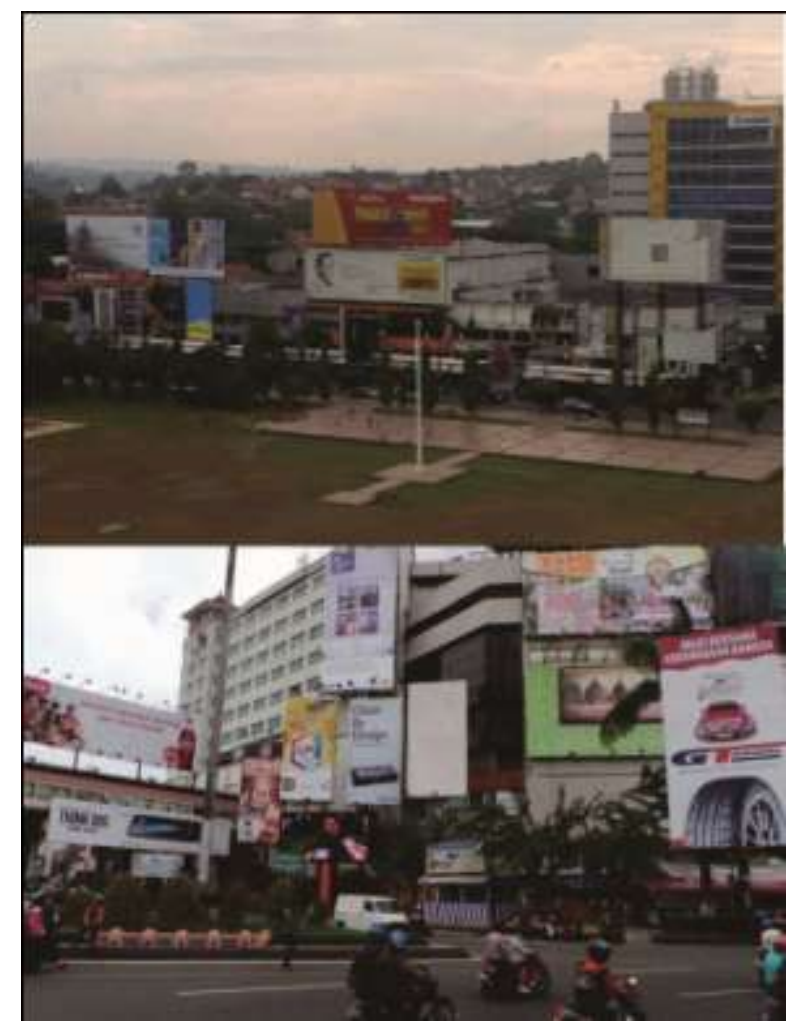

Sumber: survey lapangan, 2014

Gambar 8 : Pemasangan media ruang luas berupa papan reklame tidak memperhatikan unsur skala, proporsi, dan bentuk yang serasi dengan lingkungan mengakibatkan rusaknya tatanan visual ruang kota

Ruang publik tidak hanya berada di darat / diatas tanah, namun juga yang berada di udara. Pemanfaatan media iklan di udara merupakan "penjarahan" yang justru dilakukan oleh sebagian masyarakat yang menggunakan ruang publik sebagai tempat usaha, sedangkan "penjarahan" ruang publik oleh pemerintah berupa "penyewaan space terbuka" kepada perusahaan pemasang iklan dengan dalih untuk PAD. "Penjarahan" ruang publik tersebut disebut pula dengan privatisasi ruang publik dimana hak-hak masyarakat untuk dapat menikmati pandangan visual ruang kota yang indah, serasi tidak terpenuhi, namun dihadapkan kepada hutan belantara papan iklan dengan bentuk dan ukuran yang kurang sesuai. Privatisasi ruang publik untuk pemasangan media iklan hanya akan menguntungkan secara komersial pelaku-pelaku bisnis.

Dalam konteks urban design, keterkaitan media ruang luar dengan ruang publik sebagai wadah harus memperhatikan faktor visual yaitu kemudahan warga kota mendapatkan gambaran visual kawasan yang serasi, proporsional dan estetis (Whyte, 1980). 


\section{Kajian Dan Pembahasan}

Permasalahan yang jamak terjadi di kota-kota besar di Indonesia adalah minimnya ruang publik bagi warganya. Bagi penguasa dan pemegang modal, ruang publik dianggap sebagai ruang yang tidak menarik karena mempunyai nilai ekonomi yang rendah, akibatnya beberapa ruang publik yang pada awalnya tersedia kemudian menjadi hilang berubah bentuk menjadi ruang yang bernilai ekonomi tinggi. Bahkan beberapa ruang publik yang seharusnya dapat diakses oleh setiap warga saat kapanpun oleh penguasa diberi pembatasan. Kita masih ingat saat ruang publik di sekitar Monumen Nasional Jakarta diberi pagar yang tinggi karena ketakutan penguasa dan untuk membatasi ruang gerak warga yang ingin berdemonstrasi mendekati istana tempat presiden berkantor. Desain kota dengan penyediaan ruang publik yang cukup bagi warganya merupakan sebuah keharusan. Privatisasi ruang publik dan dibatasinya secara ketat penggunaan ruang-ruang terbuka kota adalah masalah krusial lainnya yang harus diperhatikan oleh penentu kebijakan (Purwanto, 2012).Tidak adanya pemahaman bahwa ruang terbuka kota sebenarnya menjadi hak publik untuk bersosialisasi, berinteraksi dan berdemokrasi, adalah pola pikir feodal dari pihak penguasa dalam memandang ruang kota sebagai aset kekuasaan. Bagi mereka, cara pandang ekonomi serta pengamanan fisik berlebih ruang publik di sekelilingnya ternyata lebih penting ketimbang upaya memberdayakan tempat-tempat terbuka umum sebagai tempat interaksi sosial dan kegiatan berdemokrasi warganya.

Ruang publik juga menjadi penting dalam hal membuat kota-kota modern semakin hidup dan berkembang sesuai dengan potensi yang ada karena berkumpulnya warga dari berbagai latar belakang dan minat yang berbeda. Di ruang publiklah warga dapat bertemu dan saling berinteraksi dengan yang lainnya. Adalah penting bahwa tempat-tempat seperti itu dibuat secara terbuka dan dapat diakses oleh siapapun sehingga warga dapat memilih untuk bersosialisasi menurut waktu luang mereka masing-masing. Seseorang dapat mengaktualisasikan dirinya secara penuh di ruang publik, dimana peran-peran sosial dan hirarki yang ada saat di rumah atau tempat kerja cenderung membatasi hal tersebut (Hariyono, 2007).

Di Indonesia, privatisasi ruang publik merupakan permasalahan yang harus dihadapi oleh kota dan warganya terkait erat dengan kekurangan dan kegagalan pemanfaatan ruang publik. Kegagalan pemanfataan ruang publik menyebabkan bergesernya fungsi utamanya dan sebaliknya, berubah menjadi ruang mati yang memunculkan penyakit sosial yang meresahkan masyarakat seperti praktek premanisme dan prostitusi. Permasalahan terbatasnya ruang publik sangat dipengaruhi oleh kebutuhan ruang untuk pembangunan ekonomi sehingga terjadi alih fungsi ruang publik menjadi ruang kegiatan ekonomi, dan mengesampingkan nilai-nilai sosialnya. Privatisasi ruang publik menurut Santoso (2006) akan menimbulkan dampak meningkatnya segregasi sosial, isu keamanan, terbentuknya kelompok eksklusif dan berbagai masalah sosial. Sehingga maraknya geng motor dan tawuran pelajar dapat dikaitkan dengan terbatasnya ruangruang terbuka yang menjadi sarana publik bagi para pemuda untuk menyalurkan hobinya dan membantunya untuk penyaluran agresivitas akibat tekanan sosial di tengah masyarakat. Tekanan tersebut juga hasil akumulasi dari persepsi kondisi-kondisi fisik kota yang dihiasi bangunanbangunan beton sebagai sesuatu yang menyesakkan.

Dewasa ini segregasi sosial banyak disumbangkan oleh pembangunan pusat-pusat perbelanjaan. Kehadiran mal dan bisnis waralaba di Indonesia memberikan dimensi positif karena membuka lapangan kerja baru, tetapi juga memberikan dimensi negatif yang mempertajam segregasi sosial (Halim, 2008). Hasil studi menunjukkan bahwa pasar modern di Indonesia tumbuh $31,4 \%$ per tahun, sedangkan pasar tradisional menyusut $8 \%$ per tahun 6 , artinya semakin terpuruknya pasar dan warung-warung tradisional, semakin berkurang fasilitas interaksi warga. Sedangkan terciptanya segregasi sosial pada pusat perbelanjaan dipengaruhi oleh faktor daya beli pengunjung dan harga barang yang ditawarkan. Meskipun mal menjadi tempat berinteraksi seperti menjadi titik bertemu masyarakat sehingga interaksi sosial lebih banyak dilakukan di

${ }^{6}$ http://www.merdeka.com/uang/ada-240-mal-dan-pusat-perbelanjaan-di-seluruh-indonesia.html 
pusat-pusat perbelanjaan, bertemu kolega, sahabat dan keluarga seringkali dilakukan di tempattempat makan dibandingkan dengan rumah kerabat atau ruang publik lainnya. Namun pada kenyataannya mal tidak benar-benar mampu menjadi ruang publik meskipun terbuka untuk umum sebagaimana pendapat Kusumawijaya (2006) bahwa mal tetap menampilkan wajah yang privat dimana didalamnya orang yang ada di mal cenderung berasal dari kalangan ekonomi tertentu. Gaya hidup masyarakatpun berubah menjadi lebih konsumtif, dan semakin memudarnya hubungan sosial.

\section{Kesimpulan Dan Saran}

\section{Kesimpulan}

Perubahan fungsi kawasan Simpang Lima dari Civic Centre menjadi Central Business District mengakibatkan penurunan kualitas ruang kota ditandai dengan "penguasaan" (privatisasi) ruang publik.

Ruang publik merupakan bagian dari sistem tata ruang perkotaan yang seharusnya mendapat perhatian pemerintah. Bahkan pembangunannya harus menjadi prioritas utama, bukan hanya mendapat sisanya, seperti kenyataan sekarang ini. Untuk melihat ramah tidaknya atau sehat tidaknya sebuah masyarakat kota tercermin dari pengelolaan ruang publiknya.

Ruang publik adalah sebagai wahana interaksi antar komunitas untuk berbagai tujuan, baik individu maupun kelompok. Dalam hal ini ruang publik merupakan bagian dari sistem sosial masyarakat yang keberadaannya tidak dapat dilepaskan dari dinamika sosial. Disamping itu, ruang publik juga berfungsi memberikan nilai tambah bagi lingkungan, misalnya segi estetika kota, pengendalian pencemaran udara, pengendalian iklim mikro, serta memberikan "image" dari suatu kota.

Privatisasi ruang publik yang menyebabkan makin sempitnya ruang publik akan menimbulkan dampak meningkatnya segregasi sosial, isu keamanan, terbentuknya kelompok eksklusif dan berbagai masalah sosial lainnya.

\section{Saran}

Agar tidak terjadi konflik dalam pemanfaatan ruang publik, dibutuhkan manajemen ruang publik yang melibatkan stakeholder yang terdiri dari unsur-unsur : pemerintah yang berfungsi sebagai mediator dan memegang kendali law enforcement, perencana kota, perancang kota, arsitek dan LSM yang mempunyai kepedulian terhadap ruang publik, kelompok masyarakat pelaku usaha dan masyarakat umum yang memanfaatkan ruang publik.

Keberadaan ruang terbuka publik merupakan suatu bentuk keharusan sekaligus adalah bagian integral kegiatan pembangunan dan keberadaan suatu kawasan perkotaan, sekaligus menciptakan kenyamanan. Oleh karena itu peran desain perkotaan menjadi sangat penting di dalam mengakomodasi kebutuhan tersebut.

\section{UCAPAN TERIMA KASIH}

Ucapan terima kasih disampaikan kepada Padmo Prabowo, Anna Wahidati dan Faza Razaka, ketiganya mahasiswa Jurusan Arsitektur Fakultas Teknik UNDIP angkatan 2010 yang telah membantu penulis mendapatkan data-data foto objek kajian. 


\section{Daftar Pustaka}

Beisi, JIA, 1997, Life in Public Spaces in a High Density Living Area dalam Proseding : The Third International Convention on Urban Planning, Housing and Design, School of Architecture National University of Singapore.

Carr, Stephen dkk.,1992, Public Space, Cambridge University Press.

Furchan, A. 2004. Pengantar Penelitian dalam Pendidikan. Yogyakarta: Pustaka Pelajar.

Garnham, Hary Launce, 1985, Maintaining The Spirit of Place, PDA Publisher Coorporation, Arizona.

Halim, DK, 2008, Psikologi Lingkungan Perkotaan, Bumi Aksara, Jakarta.

Hariyono, Paulus, 2007, Sosiologi Kota untuk Arsitek, Bumi Aksara, Jakarta

http://www-b.tempo.co.id/ang/min/02/27/kolom2.htm.

http://www.kompas.com/kompas-cetak/0110/24/metro/kemb18.htm

http://www.dbp.kerjabudaya.org/program/p-2000/dbp_18052000_ruangpublik.htm.

http://www.pikiran-rakyat.com/cetak/0303/06/0804.htm.

http://www.merdeka.com/uang/ada-240-mal-dan-pusat-perbelanjaan-di-seluruh-indonesia.html

Huat, C.B.,1992, Public Space, Design and Management, Singapore University Press.

Krier, Rob, 1979, Urban Space, Rizzoli International Publication Inc.

Kusumawijaya, Marco, 2006, Kota Rumah Kita, Penerbit Borneo, Jakarta.

Laguerre, Michel, 1994, The Informal City, Macmilan Press Ltd., London.

Lefebvre, H., 1991, The Production of Space, Blackwell Publishing.

Purwanto, Edi, 2004, Privatisasi Ruang Publik di Perkotaan, Proseding Makalah Simposium Nasional "Managing Conflicts in Public Spaces Through Urban Design, hal. 1-16.

Purwanto, Edi, 2008, Social Capital in Urban Space-Learning from Malioboro Jogjakarta, Proceding International Symposium "Architecture, Development And Urbanization" Towards Sustainable Cities In Nusantara, p.561578

Purwanto, Edi, 2010, Daya Hidup Ruang Jalan Pahlawan Semarang, Artikel Wacana Lokal Harian Suara Merdeka, 27 September 2010 hal. 7.

Purwanto, Edi, 2012, Relasi Rancangan Kota Dan Anarki Warga, Proseding Seminar Nasional "Sticks And Carrots", halaman II.209-II.219

Riyadi, Slamet, 2002, Media Ruang Luar dalam Sistem Visual Ruang Publik - Kasus : Kawasan Simpang Lima Semarang, Tesis S-2 Magister Teknik Arsitektur UNDIP (tidak dipublikasikan).

Radjawali, Irendra, 2004, Pemahaman Terhadap Pola Aktifitas Ekonomi Untuk Mengidentifikasi dan Melakukan Manajemen Konflik pada Ruang Terbuka Publik, Proseding Makalah Simposium Nasional "Managing Conflicts in Public Spaces Through Urban Design, hal. 83-91.

Santoso, J., 2006, Kota Tanpa Warga, Penerbit KPG dan Centropolis, Jakarta

Rossi, Aldo, 1982, The Architecture of The City, MIT Press.

Siswanto, Andi, 1997, Ruang Kota yang Manusiawi dalam Budihardjo : Arsitektur Pembangunan dan Konservasi, Djambatan.

Sukmadinata, Nana S. 2006. Metode Penelitian Pendidikan, Bandung : Remaja Rosda Karya.

Whyte, William H., 1980, The Social Life of Smal Urban Spaces, The Concervation Foundation, Washington DC.

Zahnd, Markus, 2009, Perancangan Kota Terpadu, Penerbit Kanisius, Yogyakarta. 